\title{
PERAN PERSEPSI POLITIK ORGANISASI, KOMITMEN AFEKTIF, KEPUASAN KERJA DAN STRES KERJA TERHADAP KEINGINAN UNTUK KELUAR DENGAN PERSEPSI DUKUNGAN ORGANISASI SEBAGAI MODERATOR (STUDY DI PT PQRS)
}

\author{
Tri Hermawan¹, Fuad Mas'ud², Mirwan Surya Perdhana \\ ${ }^{1}$ Magister Manajemen, Fakultas Ekonomika dan Bisnis, Universitas Diponegoro \\ 2 Magister Manajemen, Fakultas Ekonomika dan Bisnis, Universitas Diponegoro \\ ${ }^{3}$ Magister Manajemen, Fakultas Ekonomika dan Bisnis, Universitas Diponegoro
}

\begin{abstract}
This study aims at analyzing influences of political perception of organization, affective commitment, work satisfaction and work stress towards employee's eagerness to drop out with a variable of moderation perception of endorsement of organization. This study was conducted at PT PQRS. Analysis method used in this study was mixed method with the explanatory sequential design.The number of the sample was 157 respondents for closed questionnaire and 3 participants for opened questionnaire. The questionnaire measurement was closed with scale 1-7. In quantitative analysis data analysis used was multiple regression analysis with moderating variable and a help of SPSS 23 program. In qualitative analysis data analysis used was deskriptive analysis.

In quantitative analysis of examination findings toward hypothesis, it is indicated that variable of political perception of organization positively affects an eagerness of dropping out, affective commitment affects an eagerness of dropping out negatively, work stress positively affects an eagerness of dropping out and perception of endorsement of organization can moderate correlation between affective commitment and work stress towards an eagerness to drop out yet not between perception of endorsement of organization and work satisfaction towards employee's eagerness to drop out.

In qualitative analysis gives results that support the results of hypothesis testing where employees reveal the existence of political behavior and work stress is high enough accompanied by the level of affective commitment and job satisfaction which is low, so that it gives the impact on the high desire to get out of work. Other results indicate that organizational support can be perceived by employees so that moderation testing that is conducted get support that the desire to get out of work tends to decrease when they perceive organizational support at low levels of affective commitment and the employees' desire to get out of work tends to decrease when they perceive organizational support at the high level of work stress.
\end{abstract}

Key Words: intentions to quit, political perception of organization, affective commitment, work satisfaction, work stress, perception of organizational support.

\footnotetext{
${ }^{1}$ Corresponding author, Email: hermawant95@yahoo.co.id
} 


\section{PENDAHULUAN}

Peninjauan kembali dalam kajian teoritis yang dilaksanakan oleh banyak peneliti telah berusaha untuk menjawab pertanyaanpertanyaan tentang alasan yang membuat seseorang berniat untuk meninggalkan organisasi. Banyak kemungkinan telah dipaparkan, namun sedikit hasil temuan penelitian menunjukkan kekonsitenan, dengan kesimpulan disebabkan oleh keragaman karyawan sehingga ada banyak alasan seseorang untuk dapat meninggalkan organisasi Ongori (2007).Terlepas dari hal tersebut masalah keinginan untuk keluar memang sebuah masalah yang sangat penting untuk dapat di perhatikan karena dianggap sebagai salah satu faktor penghambat berkembangan organisasi. Tingkat turnover yang tinggi seringkali akan dapat menciptakan dampak negatif untuk organisasi dalam peningkatan biaya SDM seperti biaya rekruitmen dan pelatihan, ketidakpastian tenaga kerja juga dapat berdampak pada produktifitas karena mengganggu operasional organisasi Mosadeghrad (2013).

Berdasarkan hal tersebut maka setiap organisasi harus dapat mengidentifikasi faktor-faktor penyebab terjadinya niat untuk meninggalkan organisasi guna menjaga agar keberhasilan perusahaan bisa berjalan sesuai dengan yang diharapkan. Seperti halnya pada PT PQRS, dari hasil survey awal yang dilakukan menunjukkan bahwa tingkat keinginan untuk keluar karyawan yang cukup tinggi. PT PQRS adalah merupakan yang bergerak di bidang industri dan konstruksi di Indonesia.

Data survei keinginan untuk keluar yang diambil dari sample 50 karyawan Divisi Pusat Manajemen di PT PQRS secara acak menunjukkan hasil sebagai berikut:

\section{Tabel 1}

Data Survai Keinginan untuk keluar

\begin{tabular}{llllcc}
\hline No & \multicolumn{2}{c}{ Survei Instrumen } & Ya & Tidak & Keinginan untuk keluar \\
\hline 1 & $\begin{array}{l}\text { Aktif mencari pekerjaan lain diluar } \\
\text { pekerjaan anda saat ini }\end{array}$ & 14 & 36 & $28 \%$ \\
\hline 2 & $\begin{array}{l}\text { Mendapatkan pekerjaan lain, anda akan } \\
\text { pindah }\end{array}$ & 16 & 34 & $32 \%$ \\
\hline 3 & $\begin{array}{l}\text { Berfikir untuk menghabiskan semua karir } \\
\text { di perusahaan saat ini* }\end{array}$ & 27 & 23 & $46 \%$ \\
\hline 4 & $\begin{array}{l}\text { Sering berfikir untuk keluar dari } \\
\text { perusahaan }\end{array}$ & 14 & 36 & $28 \%$ \\
\hline 5 & $\begin{array}{l}\text { Berfikir bekerja tidak lebih dari 5 tahun di } \\
\text { perusahaan saat ini }\end{array}$ & 11 & 39 & $22 \%$ \\
\hline Total Rata-Rata & & & $31.20 \%$ \\
\hline
\end{tabular}

Sumber: data primer yang diolah, 2017

Tabel 1.1 dapat dijelaskan bahwa tingkat niat keinginan seseorang untuk keluar dari perusahaan saat ini dari survey 50 karyawan Divisi Pusat Manajemen di PT PQRS menunjukkan hasil yang cukup besar dimana tingkat keinginan untuk keluar adalah
31,20\%. Hasil ini telah di konfirmasi oleh Divisi Human Capital PT PQRS bahwa merupakan hasil yang cukup besar karena menurut tingkat rata-rata keinginan untuk keluar dalam sektor konstruksi adalah 25\%. Survei lain dari Hay Group Konsultan menyebutkan dalam survei terakhir bahwa 
rata-rata tingkat keinginan untuk keluar sektor konsutruksi berkisar $10 \%$ untuk pertahun sedangkan tingkat keinginan untuk keluar di Indonesia sendiri menempati posisi ke 3 setelah India dan Russia yaitu sebesar 25,3\% di tahun 2014 dan hal nilai tersebut diprediksi tidak akan banyak berubah hingga tahun 2018.

Menurut Kaya et al. (2016) mengemukakan bahwa salah satu faktor penyebab keinginan untuk keluar adalah persepsi politik organisasi yang di persepsikan oleh para karyawan maka akan meningkatkan tingkat keinginan untuk keluar. Senada dengan hal tersebut bahwa persepsi politik organisasi berpengaruh positif terhadap keinginan untuk keluar (Abubakar, Chauhan \& Kura 2014; Javed 2014; Daskin \& Tezer 2012; Meisler \& Vigoda-gadot 2009; Harris, Andrews \& Kacmar 2007; Miller, Rutherford \& Kolodinsky 2008; Chuang \& Lin 2003).

Menurut Margaretha (2011) dalam penelitianya menyebutkan bahwa kepuasan kerja dan komitmen organisasi karyawan memiliki pengaruh negatif terhadap keinginan untuk keluar. Hal senada disampaikan oleh beberapa peneliti terdahulu bahwa semakin tinggi tingkat kepuasan dan komitmen karyawan akan menurunkan tingkat dimana seseorang berniat untuk keluar dari organisasi saat ini (Salleh, Nair \& Harun 2012; Palupiningdyah 2014; Mahdi, Zin, Nor, Sakat \& Sulaiman 2012; Olusegun 2013).

Menurut Arshadi \& Damiri (2013) dalam penelitianya juga memberikan dukungan bahwa stres kerja berpengaruh positif terhadap tingkat keinginan untuk keluar karyawan, semakin tinggi tingkat stres kerja yang dialami karyawan akan sangat memungkinkan seseorang berniat untuk meninggalkan organisasi. Hasil tersebut juga didukung oleh beberapa peneliti terdahulu seperti (Mxenge, Dywili \& Bazana 2014; Palupiningdyah 2014).

Meskipun beberapa kajian memberikan bukti bahwasanya variabel kerja seperti kepuasan kerja, komitmen, stres kerja dan persepsi politik organisasi memberikan berkontribusi akan hadirnya keinginan untuk keluar namun hasil-hasil tersebut dianggap belum sepenuhnya konsisten karena dalam beberapa studi juga menemukan hasil yang cukup beragam (Tnay et al., 2013), Ibrar (2015), Delle (2013). Hubungan ketidakkonsisten di atas mungkin saja dapatdijelaskan bahwa adanya variable ketiga yang dapat melemahkan hubungan Pada beberapa studi mengemukakan bahkan bahwa persepsi dukungan organisasi mempunyai peran moderat terhadap hubungan antara persepsi politik organisasi, komitmen organisasi, kepuasan kerja dan stres kerja, terhadap keinginan untuk keluar, dimana hadirnya persepsi dukungan organisasi yang tinggi dapat meningkatkan komitmen kerja, kepuasan kerja dan menurunkan stres kerja yang pada kaitanya akan menurunkan tingkat keinginan untuk keluar (Kalidass \& Bahron 2016; Perryer, Jordan, Firns \& Travaglione 2010; Pathak 2012). Miller et al. (2008).

Berdasarkan berdasarkan fenomena yang terjadi di PT PQRS maka penulis termotivasi untuk mengambil judul "Analisis Peran Persepsi Politik Organisasi, Komitmen Afektif, Kepuasan Kerja dan Stres Kerja terhadap Keingingan untuk Keluar dengan Persepsi Dukungan Organisasi sebagai Moderator (Study di PT PQRS)".

\section{TELAAH PUSTAKA}

Penelitian ini menganalisis tentang peran persepsi politik organisasi, komitmen afektif, kepuasan kerja dan stres kerja terhadap keingingan untuk keluar dengan persepsi 
dukungan organisasi sebagai moderator, variabel dependen terdiri dari keinginan untuk keluar sebagai indikator sumber masalah perusahaan. Variabel independen terdiri dari persepsi politik organisasi, komitmen afektif, kepuasan kerja dan stres kerja sebagai variabel prediktor dan variabel persepsi dukungan organisasi sebagai variabel moderasi

\section{Hubungan Persepsi Politik Organisasi dengan Keinginan untuk keluar}

Persepsi politik organisasi merupakan suatu kadar atau derajat karyawan dalam mempersepsikan praktik politik di lingkungan kerjanya, mengutamakan kepentingan individu daripada kepentingan organisasi, serta adanya ketidakadilan dalam lingkungan organisasi Kacmar \& Carlson (1997). Senada dengan hal tersebut bahwa Ferris (1989) menyampaikan bahwa tingkat politik dalam organisasi cenderung untuk menciptakan kekecewaan yang cukup kuat pada diri seseorang sehingga menimbulkan niat untuk keluar. Hal tersebut dapat terjadi karena kehadiran politik dalam suatu organisasi seringkali menghadirkan tingkat distribusi ketidakadilan yang tinggi sehingga melemahkan tingkat kepercayaan yang kemudian berimbas kepada tingginya niat keluar atau turnover.

H1: Persepsi Politik Organisasi berpengaruh positif terhadap Stress Kerja Karyawan di PT PQRS.

\section{Hubungan Komitmen Afektif dengan Keinginan untuk keluar}

Studi penelitian terdahulu telah memberikan banyak dukungan bahwa komitmen afektif merupakan salah satu faktor yang memiliki pengaruh signifikan terhadap hadirnya keinginan untuk keluar Larkin et al., (2016) memnyampaikan bahwa komitmen afektif yang dimiliki oleh setiap karyawan mempengaruhi tingkat keputusan seseorag untuk tetap tinggal atau keinginan untuk keluar, semakin tinggi komitmen afektif yang dimiliki oleh seseorang maka akan semakin loyal seseorang terhadap organisasi sehingga menurunkan tingkat keinginan untuk keluar. Senada dari hal tersebut beberapa peneliti menemukan hasil yang hampir sama (Priya \& Sundaram 2016; Karatepe 2013).

H2: Komitmen afektif berpengaruh negatif terhadap Keinginan untuk keluar Karyawan di PT PQRS.

\section{Hubungan Kepuasan kerja dengan Keinginan untuk keluar}

Kepuasan kerja telah berulang kali diidentifikasi sebagai alasan utama mengapa karyawan meninggalkan pekerjaan mereka. (Mahdi et al. 2012) membuktikan dalam explorasi dari dampak kepuasan kerja terhadap keinginan untuk keluar di sebuah perusahaan percetakan yang ada di Malaysia menunjukkan bahwa kepuasan kerja berhubungan negatif signifikan terhadap keinginan untuk keluar, semakin tinggi tingkat kepuasan kerja yang dirasakan oleh karyawan maka akan semakin rendah tingkat keinginan untuk keluar yang ada dalam perusahaan. Beberapa peneliti sejenis juga menyampaikan hal yang hampir senada seperti (Larkin, Diaz \& Vega 2016; Priya \& Sundaram 2016; Olawale 2016; Nizam, Ruzainy, Sarah, Santhasaran \& Balasubramaniam 2016; Sandhar \& Verma 2014; Kafashpoor, Sadeghian, Shakori \& Kavoosi 2014).

H3: Kepuasan kerja berpengaruh negatif terhadap Keinginan untuk keluar Karyawan di PT PQRS.

\section{Hubungan Stres kerja dengan Keinginan} untuk keluar

Pada studi lampau telah banyak yang memberikan bukti keterkaitan antara stres kerja dan keinginan untuk keluar, menurut 
Ahania et al. (2016) menyampaikan memberikan bukti dalam ekplorasi hubungan antara stres kerja dan keinginan untuk keluar di pada 230 pekerja dari staf perawat rumah sakit di Universitas Teheran of Medical Science, memberikan buki bahwa stres kerja berkorelasi positif terhadap keinginan untuk keluar, hal ini menuju pada kesimpulan bahwa semakin tinggi tingkat stres yang dialami oleh para perawat dalam rumah sakit maka akan semakin tinggi kemungkinan tingkat seseorang perawat dalam rumah sakit untuk meninggalkan perusahaan. Sejumlah penelitian lain yang sejenis juga memberikan hasil yang hampir senada seperti (Mxenge \& Dywili 2014; Parvaiz, Batool, Khalid 2015; Arshadi \& Damiri 2013; Lee \& Mahfar 2013; Mosadeghrad 2013; Kuo \& Lin 2013; Dywili 2015).

H4: Stres kerja berpengaruh positif terhadap Keinginan untuk keluar karyawan di PT $P Q R S$.

Hubungan Persepsi Politik Organisasi terhadap Keinginan untuk Keluar dengan Moderasi Persepsi Dukungan Organisasi

Persepsi dukungan organisasi telah dijelaskan oleh para peneliti sebagai keyakinan dan pikiran karyawan mengenai sejauh mana organisasi mereka peduli tentang kesejahteraan mereka dan memberikan pentingnya untuk usaha mereka. Rhoades \& Eisenberger (2002). Penelitian sebelumnya telah menunjukkan bahwa ketika karyawan merasa bahwa organisasi mereka telah memberikan dukungan kepada mereka mungkin akan timbul perasaan positif yang akan berdampak kepada bermacam-macam sikap kerja yang konstruktif dan perilaku seperti kepuasan kerja, komitmen organisasi, keterlibatan kerja, prestasi kerja dan perilaku kewarganegaraan organisasi (Eisenberger, Huntington, Hutchison \& Sowa 1986; Cropanzano, Howes, Grandey \& Toth 1997;
Rhoades \& Eisenberger 2002; Randall, Cropanzano, Bormann \& Birjulin 1999).

Pada tinjauan literatur terdahulu yang mengeksplorasi hubungan antara politik organisasi dengan beberapa hasil kerja seperti komitmen, stres kerja, kepuasan kerja juga terbukti bahwa persepsi dukungan organisasi dapat menjadi variabel moderat yang dapat melemahkan peran serta persepsi politik organisasi yang dirasakan dalam memberikan dampak negatif terhadap variabel-variabel kerja tersebut (Miller, Rutherford \& Kolodinsky 2008; Bukhari \& Kamal 2015; Jamil, Rana \& Raja 2012). Hadirnya persepsi politik organisasi merupakan salah satu faktor yang menghambat yang dapat mempengaruhi perilaku seseorang berperilaku positif sehingga menimbulkan berbagai bentuk penyakit seperti tingginya keinginan untuk keluar, absensi dan rendahnya komitmen afektif maupun kepuasan kerja Bukhari \& Kamal (2015).

H5: Persepsi dukungan organisasi memoderasi hubungan antara persepsi politik organisasi terhadap keinginan untuk keluar karyawan PT PQRS

Hubungan Komitmen Afektif terhadap Keinginan untuk Keluar dengan Moderasi Persepsi Dukungan Organisasi

Pada umumnya persepsi dukungan organisasi berhubungan positif dengan komitmen organisasional afektif. Hubungan ini dapat dijelaskan dengan teori dukungan organisasional (organizational support theory), teori kontrak psikologis (psychological contract theory), teori identitas sosial (social identity theory) dan teori pertukaran sosial (social exchange theory). Norma pertukaran timbal balik (reciprocity norm) juga menyatakan bahwa POS yang tinggi dapat memperkuat komitmen organisasional, khususnya komitmen organisasional afektif. Berdasarkan teori 
dukungan organisasional, teori identitas sosial, teori pertukaran sosial, dan norma pertukaran timbal balik, POS berpengaruh pada komitmen afektif (Miao, 2011).

Teori dukungan organisasional juga menyatakan bahwa POS akan memperkuat komitmen organisasional afektif individu Eisenberger et al (1986) yang didefinisikan sebagai identifikasi individu dengan keterlibatan dalam organisasi dan hubungan emosional dengan organisasi Meyer \& Allen (1990). Teori dukungan organisasional menyatakan bahwa POS dapat menimbulkan perasaan bertanggung jawab membantu organisasi dalam mencapai sasarannya, mempunyai komitmen organisasional afektif, dan mendorong harapan bahwa kinerja penyelia akan dicatat dan dihargai sehingga dengan meningkatnya komitmen afektif seseorang maka akan menurunkan tingkat keinginan seseorang untuk keluar Rhoades \& Eisenberger (2002).

H6: Persepsi dukungan organisasi memoderasi hubungan antara komitmen afektif terhadap keinginan untuk keluar karyawan $P T P Q R S$.

\section{Hubungan Kepuasan Kerja terhadap Keinginan untuk Keluar dengan Moderasi Persepsi Dukungan Organisasi}

Persepsi dukungan organisasional berhubungan dengan suatu kondisi di mana karyawan merasa bahwa organisasi yang memekerjakan mereka ingin memberikan kompensasi secara adil terhadap usaha atau kinerja, membantunya memenuhi kebutuhan, memberi pekerjaan menarik dan dapat memotivasi, dan memberikan kepadanya kondisi kerja yang memenuhi (Eisenberger et al., 1986; Rhoades \& Eisenberger, 2002) menyatakan bahwa dengan adanya dukungan organisasi yang dirasakan memenuhi kebutuhan emosional dan sosial dan akibatnya karyawan akan lebih menikmati pekerjaan mereka.

Kepuasan kerja ditemukan berhubungan dengan POS sesuai dengan penelitian Shore dan Tetrick (1991), dimana karyawan mengharapkan kebutuhannya dapat terpenuhi, ketika kebutuhannya tidak terpenuhi maka baik organisasi maupun karyawan akan merasakan dampak dari menurunnya kepuasan kerja yaitu seperti: turnover, menurunnya performa kerja, dan menurunnya motivasi (Shore \& Tetrick, 1991). Oleh karena itu bila organisasi tidak dapat memenuhi kebutuhan karyawan dengan menunjukkan kepedulian dan memperhatikan kesejahteraan karyawan, maka karyawan akan merasakan penurunan kepuasan kerja. Karyawan dengan POS yang tinggi akan merasa pekerjaan yang dilakukan lebih memuaskan dan akan cenderung berkurang keinginannya untuk meninggalkan pekerjaan Rhoades \& Eisenberger (2002).

H7: Persepsi dukungan organisasi memoderasi hubungan antara kepuasan kerja terhadap keinginan untuk keluar karyawan PT PQRS.

Hubungan Stres Kerja terhadap Keinginan untuk Keluar dengan Moderasi Persepsi Dukungan Organisasi

Pathak (2012) yang mencoba mengeksplorasi peran moderasi persepsi dukungan organisasi terhadap stres kerja dan kepusaan kerja pada 200 manager perusahaan swasta di New Delhi bahwa peran moderasi dari persepsi dukungan organisasi berhasil untuk menurunkan stress kerja dan meningkatkan kepuasan kerja sehingga keinginan untuk keluar akibat stres kerja yang tinggi dapat turun.

Menurut studi oleh Leather et al. (1998) dukungan organisasi yang dirasakan mempunyai hubungan negatif antara karyawan dalam menerima kekerasan atau intimidasi dan kesejahteraan yang dialami 
oleh karyawan tersebut. Dukungan organisasi dengan memberikan materi serta dukungan emosional, diharapkan dapat mengurangi respon psikologis emosional destruktif misalnya gugup untuk stres pekerjaan seperti beban kerja yang tinggi (George et al., 1993). Akibatnya dukungan organisasi mungkin memainkan peran shock absorber dalam mengurangi efek stres di lingkungan kerja yang kemudian akan memberikan dampak investasi positif dengan menurunnya tingkat keinginan seseorang untuk keluar Rhoades \& Eisenberger (2002).

H8 : Persepsi dukungan organisasi memoderasi hubungan antara stres kerja terhadap keinginan untuk keluar karyawan PT PQRS.

Berdasarkan pada hubungan antar variabel diatas dan juga beberapa hasil penelitian yang mendasari pengambilan hipotesis maka kerangka pemikiran dalam penelitian ini digambarkan dalam bentuk model penelitian sebagai berikut

\section{Gambar 1}

Kerangka Pemikiran

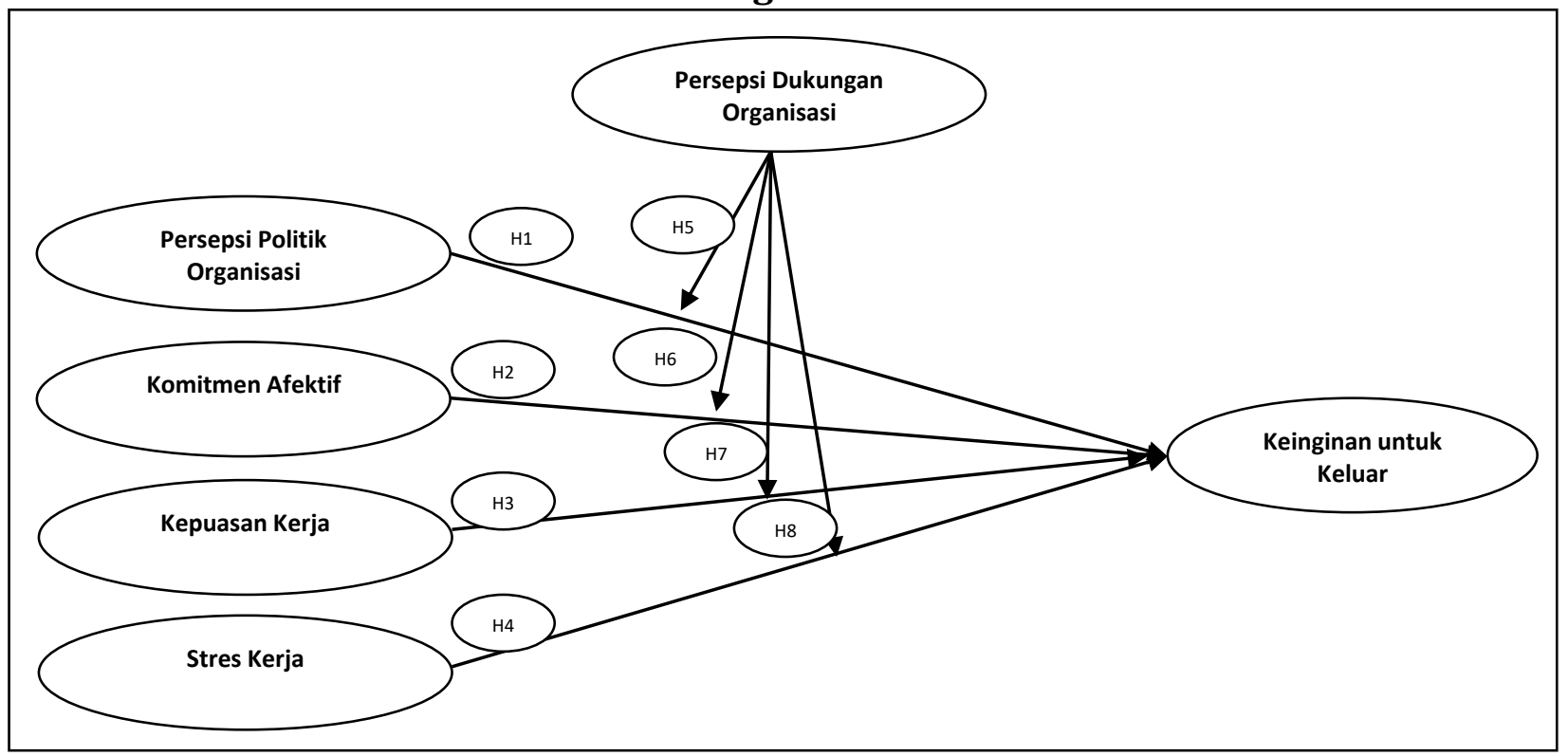

Sumber: dikembangkan untuk penelitian ini, 2017

Variabel Penelitian dan Definisi Operasional Variabel

Dependent variable merupakan suatu variabel terikat yang menjadi pusat peneliti untuk dapat memahami, mendiskipsikan atau menjelaskan maupun memprediksikanya. Variabel dependen pada penelitian ini adalah keinginan untuk keluar Sekaran \& Bougie (2010). Keinginan untuk keluar pada penelitian ini diukur menggunakan 5 indikator dari Wayne et al. (1997) dalam Mas'ud (2004).

Independent variable merupakan suatu variabel bebas atau tidak terikat yang dapat mempengaruhi secara positif maupun negatif variabel terikat (dependent variable). Variabel independen pada penelitian ini adalah persepsi politik organisasi, komitmen afektif, kepuasan kerja \& stres kerja Sekaran \& Bougie (2010). Persepsi politik organisasi 
diukur menggunakan 3 dimensi yaitu General Political Behavior (Perilaku Politik Secara Umum), Go Along to Get Ahead (Maju untuk Mencapai Tujuan) dan Pay and Promotion Policies (Kebijakan Pembayaran Upah dan Promosi) dengan menggunakan 9 indikator dari Kacmar \& Carlson (1997). Komitmen afektif pada penelitian ini diukur menggunakan 6 indikator dari Meyer \& Allen (1997). Kepuasan kerja pada penelitian ini diukur menggunakan 5 dimensi yaitu gaji, promosi, rekan kerja, penyelia dan pekerjaan itu sendiri dengan 15 indikator pertanyaan dari Celluci dan De Vries (1978) dalam Mas'ud (2004) dan stres kerja pada penelitian ini diukur menggunakan 3 dimensi yaitu gejala fisiologis, gejala psikologis dan gejala perilaku dengan 6 indikator pertanyaa dari robbins (2008).

Moderating variable merupakan suatu variabel yang dapat memperkuat maupun memperlemah hubungan antara variabel independen dan variabel dependen. Variable moderat pada penelitian ini adalah persepsi dukungan organisasi Sekaran \& Bougie (2010). Pada penelitian ini persepsi dukungan organisasi diukur menggunakan 4 dimensi yang meliputi fairness (keadilan), supervisor support (dukungan atasan), penghargaan dan kondisi kerja dengan 8 indikator pertanya dari Eisenberger et al. (2002)

\section{METODE PENELITIAN Jenis dan Sumber Data}

Jenis penelitian dalam penelitian ini adalah penelitian mixed methods atau tergolong dalam jenis explanatory design. Adapun data yang digunakan dalam penelitian ini ada 2 yaitu data data primer dan sekunder Sekaran (2006).

\section{Populasi dan Sampel}

Penentuan ukuran sampel pada penelitian ini menggunakan sampling jenuh atau metode sensus yang menjadikan semua anggota populasi menjadi sampel pada penelitian ini Sugiyono (2004) maka jumlah sampel yang digunakan pada penelitian ini adalah 157 responden.

\section{Metode Pengumpulan Data}

Data pada penelitian ini dikumpulkan menggunakan 3 metode yaitu metode kuesioner, metode wawancara dan metode dokumentasi.

\section{Metode Kuisioner}

Dalam penelitian ini peneliti menggunakan 2 kuesioner yaitu kuesioner terbuka dan tertutup. Kuesioner tertutup dibagikan kepada pegawai di perusahaan PT PQRS dibagian Pusman sebanyak 157 orang. Pengukuran kuesioner dalam penelitian ini menggunakan skala likert atau interval point 1-7 dari sangat tidak setuju sampai sangat setuju.

\section{Metode Wawancara}

Metode wawancara peneliti digunakan untuk menggali informasi dari beberapa responden yang berhasil dikonfimasi setelah pengolahan hasil analisis kuantitatif yang didapat dari kuesioner terbuka. Jumlah responden yang telah bersedia untuk di wawancara sebanyak 3 responden yang ke tiganya berasal dari biro yang berbeda di PT PQRS.

\section{Metode Dokumentasi}

Metode dokumentasi digunakan untuk mengumpulkan data sekunder yang berupa data pegawai dan gambaran umum tentang PT PQRS, jurnal, artikel, datau data-data penelitian sebelumnya.

\section{Metode Analisis Data}

Dalam penelitian ini, proses analisis data peneliti menggunakan pendekatan Mixed Methods, yaitu menggabungkan pengumpulan data menggunakan pendekatan kualitatif dan kuantitatif melalui beberapa fase proses penelitian. Terdapat beberapa desain dalam pendekatan Mixed Methods, 
pada penelitian ini desain penelitian yang digunakan adalah The Explanatory Sequential
Design dengan alur tahapan analisi data sebagai berikut:

\section{Gambar 2}

\section{The Explanatory Sequential Design}

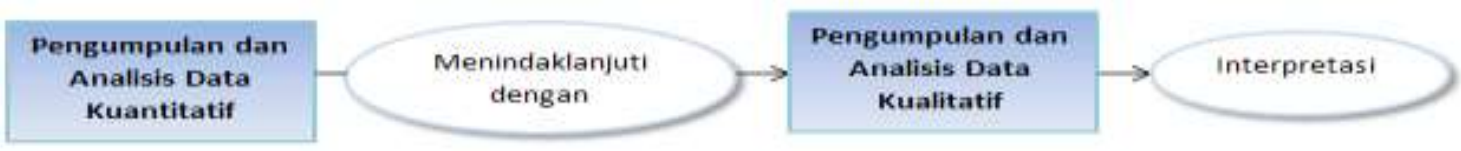

Dalam desain The Explanatory Sequential Design alur tahapan analisis data dibagi menjadi 2 tahap interaktif yang berbeda. Desain ini dimulai dengan pengumpulan dan analisis data kuantitatif, yang memiliki prioritas untuk menangani pertanyaanpertanyaan penelitian. Tahap pertama ini selanjutnya diikuti oleh pengumpulan dan analisis data kualitatif. Kedua, fase kualitatif penelitian dirancang sehingga mengikuti dari hasil pertama, fase kuantitatif. Peneliti menafsirkan hasil kualitatif untuk membantu menjelaskan hasil penelitian kuantitatif pada tahap awal. Sebagai contoh, peneliti mengumpulkan dan menganalisis data kuantitatif untuk mengidentifikasi, selanjutnya peneliti melakukan wawancara kualitatif untuk menjelaskan hasil sebelumnya.

\section{Analisis Data Kuantitatif}

Tahapan-tahapan analisis kuantitatif

1. Uji Reliabilitas dan Validitas

Adalah suatu indeks yang menunjukan sejauh mana hasil suatu pengukuran dapat dipercaya. Sedangkan validitas menunjukkan sejauh mana ketepatan dan kecermatan suatu alat ukur dalam melakukan fungsi alat ukurnya.

2. Uji Penyimpangan Asumsi Klasik

a) Uji Normalitas

Uji normalitas ini bertujuan untuk mengetahui perlakuan akan berdistribusi normal atau tidak. b) Uji Heteroskosdasitas

Uji heterokedastisitas dilakukan untuk menguji apakah dalam sebuah model regresi terjadi ketidaksamaan varians dari residual dari satu pengamatan satu ke pengamatan yang lain.

c) Uji Multikoleneritas

Uji multikolinearitas dilakukan untuk menguji apakah pada model regresi ditemukan adanya korelasi antar variabel independent

3. Analisis Regresi Linier Berganda dengan Variabel Moderasi

Analisis ini menunjukan bahwa variabel dependen akan bergantung (terpengaruh) pada lebih dari satu variabel independen Bentuk analisis regresi berganda dengan variabel moderasi ini adalah:

$$
\begin{aligned}
& Y=\beta_{1} X_{1}+\beta_{2} X_{2}+\beta_{3} X_{3}+\beta_{4} X_{4}+\beta_{5} Z_{1}+ \\
& \beta_{6} \mathrm{X}_{1} * \mathrm{Z}_{1}+\beta_{7} \mathrm{X}_{2} * \mathrm{Z}_{1}+\beta_{8} \mathrm{X}_{3} * \mathrm{Z}_{1}+\beta_{9} \mathrm{X}_{3} * \mathrm{Z}_{1} \\
& \text { Keterangan. } \\
& \beta=\text { Koefisien regresi } \\
& \mathrm{Y}=\text { Variabel terikat yaitu keinginan } \\
& \text { untuk keluar karyawan } \\
& \mathrm{X}_{1}=\text { Variabel bebas yaitu persepsi } \\
& \text { politik organisasi } \\
& \mathrm{X}_{2}=\text { Variabel bebas yaitu komitmen } \\
& \mathrm{Z}_{1}=\text { Variabel Moderasi }
\end{aligned}
$$


4. Uji Hipotesis

a) Uji t (Pengujian signifikansi secara parsial) Uji t digunakan untuk menguji signifikansi hubungan antara variabel $\mathrm{X}$ dan variabel $\mathrm{Y}$, apakah variabel $\mathrm{X} 1$, $\mathrm{X} 2$ benar-benar berpengaruh terhadap variabel $Y$.

b) Uji F (Pengujian signifikansi secara simultan) Uji $F$ pada dasarnya menunjukkan apakah semua variabel bebas yang dimasukkan dalam model mempunyai pengaruh secara bersama-sama terhadap variabel terikat. Uji koefisien regresi serentak (F test) dilakukan untuk melihat Pengujian ini dilakukan dengan membandingkan nilai Fhitung dengan Ftabel.

c) Uji R2 (Perubahan Perubahan Adj R Square)Uji ketepatan perkiraan (Perubahan Adj R Square) dilakukan

untuk mendeteksi ketepatan yang paling baik dalam analisis regresi.

\section{Analisis Data Kualitatif}

Pada tahap ini uji kualitatif dirancang untuk mengikuti hasil dari uji kuantitatif dalam membantu menafsirkan lebih mendalam terkait dari hasil pengujian pertama pada analisis kuantitatif dengan menggunakan uji deskriptif. Pengambilan data wawancara dilakukan dengan menggunakan tiga responden dimana ketiganya berasal dari 3 divisi berbeda di Pusat Manajemen di PT PQRS.

\section{HASIL DAN PEMBAHASAN \\ Deskripsi Sampel Penelitian}

Deskripsi Sampel Penelitian Berdasarkan hasil tabulasi jawaban kuesioner terhadap 149 responden, frekuensi dan presentase responden terhadap jenis kelamin, usia, masa kerja, dan pendidikan terakhir dapat dilihat pada tabel 1 di bawah ini

Tabel 3

Data Demografi Responden

\begin{tabular}{cccc}
\hline Variabel Kontrol & Karakteristik & Frekuensi & Presentase \\
\hline Umur & $20-30$ & 71 & $47,7 \%$ \\
& $31-40$ & 41 & $27,5 \%$ \\
& $>41$ & 37 & $24,8 \%$ \\
Jenis Kelamin & & & \\
& Laki-laki & 139 & $93,33 \%$ \\
Tingkat Pendidikan & Perempuan & 10 & $6,66 \%$ \\
& & & \\
& SMA Sederajat & 56 & $36 \%$ \\
& DIII & 8 & $4 \%$ \\
Masa Kerja & S2/S3 & 85 & $57 \%$ \\
& & 5 & $3 \%$ \\
& $0-3$ & 85 & $57 \%$ \\
& $4-10$ & 19 & $12 \%$ \\
& $11-20$ & 10 & $7 \%$ \\
& $>20$ & 35 & $24 \%$ \\
\hline
\end{tabular}

Sumber: Data primer yang diolah, 2017 


\section{Uji Reliabilitas dan Validitas}

Pada uji kualitas data, dilakukan beberapa uji untuk mengukur kualitas data yaitu uji reliabilitas dan uji validitas. Pada uji reliabilitas, variabel persepsi politik organisasi cronbach alpha sebesar 0.790, komitmen afektif 0.819 , kepuasan kerja 0.777 , stres kerja 0.819 , persepsi dukungan organisasi 0.798 dan keinginan untuk keluar 0.825 Menunjukan bahwa skor $\alpha$ masingmasing variabel diatas 0.60 , sehingga masingmasing variabel lolos dari uji reliabilitas.

Uji validitas menggunakan Confirmatory Factor Analysis (CFA), uji validitas dilakukan dengan melihat nilai dari KMO lebih dari 0,5 dan nilai signifikansi Barlett's Test of Sphrecity tidak lebih dari 0,05. Skor KMO, variabel persepsi politik organisasi sebesar 0.937, komitmen afektif sebesar 0.875, kepuasan kerja sebesar 0.941, stres kerja sebesar 0.907 , persepsi dukungan organisasi sebesar 0.913 dan keinginan untuk keluar sebesar 0.881 dengan skor Barlett's Test of Sphrecity masing-masing variabel sebesar 0,000 menunjukan bahwa variabel memenuhi syarat validitas dan penelitian ini valid.

\section{Uji Asumsi Klasik}

Uji asumsi klasik meliputi uji normalitas, uji multikolinieritas dan uji heteroskedastisitas. Pada uji normalitas menggunakan metode P-Plot Skewness dan Kurtosis, masing-masing variabel memenuhi syarat normalitas karena masih berada pada rentang data menyebar di sekitar garis diagonal dan mengikuti arah garis diagonal,horisontal. Sedangkan uji multikolinieritas melihat pada nilai tolerance dan VIF, pada nilai tolerance tidak kurang dari 0,1 dan VIF tidak lebih dari 10. Variabel persepsi politik organisasi memiliki nilai tolerance sebesar 0.693 dan VIF 1.442, Variabel persepsi politik organisasi memiliki nilai tolerance sebesar 0.693 dan VIF 1.442, Variabel komitmen afektif memiliki nilai tolerance sebesar 0.587 dan VIF 1.703, Variabel kepuasan kerja memiliki nilai tolerance sebesar 0.726 dan VIF 1.377, Variabel stres kerja memiliki nilai tolerance sebesar 0.614 dan VIF 1.630. Sehingga masing-masing variabel tidak memiliki gejala multikolinieritas. Untuk uji heteroskedastisitas menggunakan uji Park, yaitu teknik meregresikan variabel independen terhadap mengkuadratkan residual dan nilai signifikansi harus lebih dari 0,05 . Pada penelitian ini menunjukan signifikansi diatas 0,05 sehingga tidak terdapat gejala heteroskedastisitas.

\section{Analisis Regresi Berganda dengan Variabel Moderating}

Pengujian hipotesis pada penelitian ini menggunakan uji $t$ untuk mengetahui hubungan antara variabel bebas terhadap variabel terikat secara parsial. Ketentuan pada uji $\mathrm{t}$ yaitu $\mathrm{t}$ hitung>t tabel dengan signifikansi dibawah 5\% atau 0,05. Hasil dari uji t dapat dilihat pada tabel berikut :

\section{Tabel 4}

Uji Regresi Berganda dengan Variabel Moderating

\begin{tabular}{l|c|c}
\hline Variabel & t & Sig \\
\hline $\begin{array}{l}\text { persepsi politik organisasi } \\
(\mathrm{X} 1)\end{array}$ & 6.159 & .000 \\
\hline komitmen afektif (X2) & -4.357 & .000 \\
\hline kepuasan kerja (X3) & -6.562 & .000 \\
\hline stres kerja (X4) dukungan & 4.344 & .000 \\
\hline persepsi & -3.389 & .001 \\
\hline
\end{tabular}




\begin{tabular}{l|c|c}
\hline organisasi (M) & & \\
\hline $\mathrm{X} 1 * \mathrm{M}$ & 1.709 & .090 \\
\hline $\mathrm{X} 2 * \mathrm{M}$ & -3.133 & .002 \\
\hline $\mathrm{X} 3 * \mathrm{M}$ & 1.711 & .089 \\
\hline $\mathrm{X} 4 * \mathrm{M}$ & -2.174 & .031 \\
\hline
\end{tabular}

Dengan total responden (n) yaitu 149, maka didapatkan $\mathrm{t}$ tabel sebesar 1.976. Berdasarkan uji t pada tabel diatas dapat diketahui bahwa :

1. Nilai t hitung variabel persepsi politik organisasi sebesar 6.159 dengan tingkat signifikansi 0,000. Nilai t hitung (6.159) > t tabel $(2,01)$ dan tingkat signifikansi dibawah 5\%, maka dapat disimpulkan bahwa persepsi politik organisasi berpengaruh positif signifikan terhadap keinginan untuk keluar.

2. Nilai t hitung variabel komitmen afektif sebesar -4.357 dengan tingkat signifikansi 0,000 . Nilai $\mathrm{t}$ hitung (4.357) $>\mathrm{t}$ tabel $(2,01)$ dan tingkat signifikansi diatas $5 \%$, maka dapat disimpulkan bahwa komitmen afektif berpengaruh negatif terhadap keinginan untuk keluar.

3. Nilai $t$ hitung variabel kepuasan kerja sebesar -6.562 dengan tingkat signifikansi 0,000 . Nilai $\mathrm{t}$ hitung $(-6.562)>\mathrm{t}$ tabel $(2,01)$ dan tingkat signifikansi diatas $5 \%$, maka dapat disimpulkan bahwa kepuasan kerja berpengaruh negatif terhadap keinginan untuk keluar.

4. Nilai t hitung variabel stres kerja sebesar 4.344 dengan tingkat signifikansi 0,000. Nilai thitung $(4.344)>\mathrm{t}$ tabel $(2,01)$ dan tingkat signifikansi dibawah 5\%, maka dapat disimpulkan bahwa stres kerja berpengaruh positif signifikan terhadap keinginan untuk keluar.

5. Nilai t hitung variabel moderating $\left(\mathrm{X} 1^{*} \mathrm{M}\right)$ sebesar 1.709 dengan tingkat signifikansi .090. Nilai t hitung $(1.709)<\mathrm{t}$ tabel $(2,01)$ dan tingkat signifikansi diatas 5\%, maka dapat disimpulkan bahwa persepsi dukungan organisasi tidak dapat memoderasi hubungan antara persepsi politik organisasi terhadap keinginan untuk keluar.

6. Nilai thitung variabel moderating $(\mathrm{X} 2 * \mathrm{M})$ sebesar -3.133 dengan tingkat signifikansi .002 . Nilai $\mathrm{t}$ hitung $(-3.133)<\mathrm{t}$ tabel $(2,01)$ dan tingkat signifikansi diatas $5 \%$, maka dapat disimpulkan bahwa persepsi dukungan organisasi memoderasi hubungan antara komitmen afektif terhadap keinginan untuk keluar .

7. Nilai t hitung variabel moderating $(\mathrm{X} 3 * \mathrm{M})$ sebesar 1.711 dengan tingkat signifikansi .089. Nilai t hitung $(1.711)<\mathrm{t}$ tabel $(2,01)$ dan tingkat signifikansi diatas 5\%, maka dapat disimpulkan bahwa persepsi dukungan organisasi tidak dapat memoderasi hubungan antara kepuasan kerja terhadap keinginan untuk keluar .

8. Nilai thitung variabel moderating $(\mathrm{X} 4 * \mathrm{M})$ sebesar -2.174 dengan tingkat signifikansi .090. Nilai t hitung $(-2.174)<\mathrm{t}$ tabel $(2,01)$ dan tingkat signifikansi diatas $5 \%$, maka dapat disimpulkan bahwa persepsi dukungan organisasi memoderasi hubungan antara stres kerja terhadap keinginan untuk keluar.

\section{Uji Signifikansi Simultan (Uji F Statistik)}

Uji signifikansi simultan (uji statistik F) digunakan untuk menguji apakah semua variabel bebas yang dimasukkan ke dalam model mempunyai pengaruh secara bersamasama terhadap variabel terikat. Kriteria pengujian yang digunakan adalah $\mathrm{HO}$ diterima apabila nilai signifikansi $\mathrm{p}>0,05$ dan $\mathrm{HO}$ ditolak apabila nilai signifikansi $\mathrm{p}>$ 0,05 . 


\section{Tabel 5}

\section{Uji Signifikansi Simultan (Uji F Statistik)}

\begin{tabular}{ccc}
\hline Tahapan & Nilai F Statistik & Signifikasi \\
\hline Nilai F Statistik Regresi Sebelum & 114.682 & 0.000 \\
\hline Nilai F Statistik Regresi Sesudah & 67.261 & 0.000 \\
\hline
\end{tabular}

Berdasarkan hasil uji $\mathrm{F}$, yang ditunjukkan dalam Tabel 4.13 diperoleh nilai $F$ statistik regresi pertama sebesar 114.682 dengan tingkat signifikansi $\mathrm{p}=0,000$. Mengingat probabilitas $0,000<0,05$, maka model regresi dapat digunakan untuk memprediksi keinginan untuk keluar. Oleh karenanya dapat dikatakan, bahwa persepsi politik oganisasi, komitmen afektif, kepuasan kerja, stres kerja, dukungan organisasi mempunyai pengaruh yang signifikan terhadap keinginan untuk keluar karyawan di PT PQRS secara bersama-sama.

Hasil uji F pada regresi sesudah moderasi diperoleh nilai $F$ statistik sebesar 67.741 dengan tingkat signifikansi $\mathrm{p}=0,000$. Mengingat probabilitas $0,000<0,05$, maka model regresi dapat digunakan untuk memprediksi keinginan untuk keluar. Dengan kata lain dapat dikatakan, bahwa bahwa Persepsi politik oganisasi, komitmen afektif, kepuasan kerja, stres kerja, dan hubungan interaksi dengan persepsi dukungan organisasi secara bersama-sama mempunyai pengaruh yang signifikan terhadap keinginan untuk keluar karyawan di PT PQRS secara bersama-sama.

\section{Perubahan Nilai F Statistik}

Uji ini dilakukan untuk melihat sejauh mana pengaruh tiap penambahan variabel dalam tiap tahapan regresi dalam mempengaruhi variabel dependen. Berdasarkan hasil regresi pertama yang terdiri dari satu variabel bebas, yaitu persepsi politik oganisasi, komitmen afektif, kepuasan kerja, stres kerja dan regresi kedua dengan melibatkan variabel persepsi dukungan organisasi dan ketiga melibatkan interaksi antara kepuasan kerja dengan persepsi dukungan dapat diketahui perubahan nilai $\mathrm{F}$ yang dapat telihat pada tabel dibawah ini:

\section{Tabel 6}

Perubahan Nilai F Statistik

\begin{tabular}{ccc}
\hline Nilai F Statistik & Nilai F Statistik & Perubahan Nilai F ( $\Delta$ \\
Sebelum Interaksi & Sesudah Interaksi & F) \\
\hline 114.682 & 67.261 & 47.421 \\
\hline
\end{tabular}

Nilai $F$ statistik pada regresi sebelum interaksi lebih besar dibandingkan dengan nilai F pada regresi sesudah interaksi, yaitu 114.682: 67.261. Hal ini menunjukkan bahwa penambahan variabel moderasi, dalam hal ini persepsi dukungan organisasi, memperlemah pengaruh persepsi politik organisasi,komitmen afektif, kepuasan kerja, stres kerja, terhadap keinginan untuk keluar. Besarnya perubahan ditunjukkan dengan besarnya selisih antara nilai $F$ sebelum interaksi dengan nilai $\mathrm{F}$ sesudah interaksi, yaitu $(\Delta \mathrm{F})$ sebesar 47.421

\section{Uji R (Perubahan Adj R Square)}

Uji koefisien determinasi untuk mengukur seberapa kuat pengaruh dari variabel bebas terhadap variabel terikat dalam suatu penelitian. Berikut koefisien determinasi pada penelitian ini: 


\section{Tabel 7}

Perubahan Adjusted R Square

\begin{tabular}{ccc}
\hline $\begin{array}{c}\text { Nilai Adjusted R Square } \\
\text { Sebelum Interaksi }\end{array}$ & $\begin{array}{c}\text { Nilai Adjusted R Square } \\
\text { Sesudah Interaksi }\end{array}$ & $\begin{array}{c}\text { Perubahan Nilai Adjusted R } \\
\text { Square ( } \Delta \text { Adjusted R Square) }\end{array}$ \\
\hline 0.754 & 0.801 & -0.047 \\
\hline
\end{tabular}

Hasil uji koefisien determinasi (Adj R Square) pada regresi sebelum interaksi diperoleh nilai (Adj R Square) $0.754 \mathrm{Hal} \mathrm{ini}$ berarti bahwa $75.4 \%$ variabilitas keinginan untuk keluar ditentukan oleh persepsi politik organisasi $\left(\mathrm{X}_{1}\right)$, komitmen afektif $\left(\mathrm{X}_{2}\right)$, kepuasan kerja $\left(\mathrm{X}_{3}\right)$ dan stres kerja $\left(\mathrm{X}_{4}\right)$ sisanya sebesar $24.6 \%$ ditentukan oleh variabel lain. Hasil uji koefisien determinasi (R2) pada regresi setelah moderasi yang ditunjukkan dalam Tabel 4.14 diperoleh koefisien determinasi (R2) sebesar $0.801 \mathrm{Hal}$ ini berarti $80.1 \%$ variabilitas keinginan untuk keluar karyawan di PT PT PQRS dapat dijelaskan oleh persepsi politik organisasi $\left(\mathrm{X}_{1}\right)$, komitmen afektif $\left(\mathrm{X}_{2}\right)$, kepuasan kerja $\left(\mathrm{X}_{3}\right)$ dan stres kerja $\left(\mathrm{X}_{4}\right)$ dan interaksi antara persepsi dukungan organisasi dengan variabel independen. Sisanya sebesar $19.9 \%$ dijelaskan oleh variabel-variabel lain di luar model ini.

Berdasarkan kedua nilai koefisien determinasi (Adj R Square) yang diperoleh dari regresi sebelum dan sesudah interaksi dapat diketahui bahwa besarnya perubahan nilai (Adj R Square) adalah sebesar -0.047 atau mengalami penurunan.

\section{Analisis Kualitatif}

Hasil wawancara yang di peroleh membawa peneliti untuk dapat menjelaskan lebih mendalam terhadap hasil pengujian kuantatif sehingga diharapakan akan dapat mengurangi hasil bias yang ada. Dari wawancara yang dilakukan pada 3 responden yaitu pegawai biro pengadaan, biro operasional dan biro human capital peneliti mendapatkan hasil yang sebagian besar mendukung dari hasil analisis kuantitatif. Dimana sebagian besar responden mengungkapkan alasan-alasan yang melatarbelakangi meningkatnya keinginan untuk keluar dari PT PQRS. Faktor-faktor penyebab keinginan untuk keluar tersebut peneliti coba sajikan dalam bentuk tabel berikut:

\section{Tabel 8}

\section{Faktor-Faktor Penyebab Keinginan untuk Keluar di PT PQRS}

\begin{tabular}{cl}
\hline No & Faktor - Faktor Penyebab \\
\hline 1 & Tingkat Kesejahteraan \\
\hline 2 & Kondisi Perusahaan \\
\hline 3 & Pembajakan Karyawan \\
\hline 4 & Usia Karyawan \\
\hline 5 & Kebijakan Perusahaan \\
\hline
\end{tabular}

Sumber: Data primer diolah, 2017

Dari hasil rangkuman wawancara dapat disimpulkan sebagai berikut bahwa setiap faktor yang ada saling mempengaruhi satu sama lain dalam mendukung atas peningkatan dari niat atau keinginan untuk keluar yang ada di PT PQRS. Hasil yang paling sering dikeluhkan dalam menanggapi latarbelakang keinginan untuk keluar adalah 
dirasakanya tingkat kesejahteraan yang belum cukup memuaskan bila dibandingankan dengan perusahaan lain sejenis, dalam pernyataan ini secara tidak langsung mengungkapkan bahwa tingkat kepuasan kerja dan persepsi dukungan karyawan terhadap PT PQRS cukup rendah. Namun hal ini telah disadari oleh sebagian besar karyawan sebagai suatu bentuk yang wajar mengingat kondisi perusahaan saat ini dengan kinerja yang sedang menurun.

Kondisi kinerja yang menurun disebabkan oleh kurang maksimalnya hasil yang diperoleh dalam menjalankan proyekproyek yang ada ditambah lagi bahwa PT PQRS merupakan perusahaan baru dalam dunia kontruksi karena sebelumnya merambah dalam bisnis Trade dan Industri. Banyak strategi yang digunakan dalam menjalankan proyek dengan metode trial \& eror. Kondisi ini menyebabkan stres kerja yang cukup tinggi di PT PQRS,

Di luar permasalahan intern perusahaan, pembajakan SDM dari perusahaanperusahaan sejenis sangat marak terjadi untuk mencoba mengambil SDM yang potensial di PT PQRS dengan tawaran-

\section{Pembahasan}

Persepsi politik organisasi berpengaruh positif signifikan terhadap keinginan untuk keluar di PT PQRS. Walaupun tidak banyak yang bisa diungkapkan dari hasil wawancara namun beberapa responden telah memberikan beberapa data yang cukup untuk menujukkan tingkat persepsi politik yang hadir lingkungan PT PQRS seperti adanya kebijakan yang tidak memperbolehkan karyawan PT PQRS untuk dapat transfer ke holding (induk usaha), adanya indikasi penolakan kritik, adanya indikasi penggunaan kekuasan atas kelompok dan lain sebagainya. hal tersebut membuat karyawan lebih memilih untuk tawaran yang lebih menarik. Hal ini tidak dapat terelakan mengingat kondisi perusahaan saat ini dan tidak adanya peraturan yang mengatur akan sanksi dari pembajakan SDM dalam sektor kontruksi. Tinjauan ini memberikan gambaran bahwa banyaknya karyawan yang pindah ke perusahaan lain sejenis menujukkan bahwa ada permasalahan dalam tingkat komitmen karyawan yang ada di PT PQRS. Hal ini mungkin juga didukung oleh banyaknya karyawan dengan usia dan masa kerja yang relatif masih muda yang ada di PT PQRS.

Faktor pendukung lain bahwa hadirnya persepsi politik di dalam PT PQRS juga mendapatkan respon yang cukup negatif seperti adanya beberapa kebijakan yang dirasa dibuat untuk membatasi karyawan berkembang, kurang terbukanya perusahaan dalam menerima kritik, adanya pengaruh dari kelompok-kelompok yang memiliki pengaruh sehingga secara tidak langsung berdampak pada peningkatan niat atau keinginan untuk keluar yang ada di PT PQRS. Sehingga faktor-faktor dalam analisis kualitatif ini secara tidak langsung mendukung dari analisis kuantitatif.

diam dan mengikuti apa yang di perintahkan. Kebijakan promosi juga terkesan lambat untuk posisi-posisi administratif dan terkesan lebih cepat untuk posisi teknis yang dekat dengan proyek dan atasan. Persepsipersepsi yang tumbuh tersebut memberikan dampak yang negatif terhadap karyawan dengan menimbulkan rasa kekecewan dan distribusi keadilan yang tidak merata sehingga hal tersebut memberikan pengaruh terhadap peningkatan keinginan untuk keluar karyawan di PT PQRS.

Komitmen afektif berpengaruh negatif signifikan terhadap keinginan untuk keluar di PT PQRS. Indikasi komitmen afektif yang rendah di PT PQRS banyak di sebabkan oleh 
banyaknya pembajakan SDM dari perusahaan-perusahaan lain yang sejenis dengan tawaran-tawaran yang mengiurkan sehingga hal tersebut menganggu tingkat komitmen afektif karyawan. Penyebab lain bahwa sebagian besar karyawan PT PQRS di Pusat Manajemen (PUSMAN) adalah karyawan dengan usia yang relatif muda dengan masa kerja yang masih relatif pendek. Sehingga dengan komposisi tersebut maka akan lebih banyak kemungkinan untuk karyawan dapat keluar karena dengan usia yang masih relatif muda akan menyebabkan karyawan lebih agresif dan relatif bekerja untuk mencari pengalaman untuk pekerjaan yang mungkin lebih baik. Sehingga hal tersebut secara tidak langsung menurunkan tingkat komitmen afektif karyawan yang kemudian menyebabkan meningkatnya keinginan untuk keluar di PT PQRS.

Kepuasan kerja berpengaruh negatif signifikan terhadap keinginan untuk keluar di PT PQRS. Indikasi kepuasan kerja yang rendah di PT PQRS banyak disebabkan oleh tingkat kesejahteraan yang dirasakan belum cukup memuaskan dibandingan dengan perusahaan sejenis lainya seperti tingkat gaji/upah atau fasilitas-fasilitas yang lain seperti program pelatihan yang relatif jarang dirasakan oleh karyawan. Kemudian sulitnya karyawan untuk menyampaikan pendapat, ide atau masukan juga dan kebijakan promosi yang terkesan lama membuat persepsi negatif di karyawan yang menyebabkan tingkat kepuasan menjadi rendah. Tingkat kepuasan yang rendah akan berdampak pada peningkatan keinginan keinginan untuk keluar yang ada di PT PQRS.

Stres kerja yang tinggi di PT PQRS banyak di sebabkan oleh kondisi kinerja perusahaan saat ini yang sedang menurun. Kegagalan sejumlah proyek dari tendertender yang ada menyebabkan beberapa kerugian yang menyebabkan stres kerja yang meningkat. Sebab lain bahwa PT PQRS merupakan pemain baru di bidang kontruksi belum banyaknya pengalaman membuat PT PQRS banyak menggunakan strategi trial \& eror dalam pelaksanaan proyek-proyek yang ada sehingga hal tersebut secara signifikan meningkatkan stres kerja karyawan di PT PQRS. Meningkatnya stres kerja yang berkepanjangan maka berpotensi untuk meningkatkan keinginan untuk keluar di PT PQRS.

Pada pengujian moderasi didapatkan hasil bahwa persepsi dukungan organisasi berhasil menjadi pemoderasi hubungan antara persepsi politik organisasi, komitmen afektif, kepuasan kerja dan stres kerja terhadap keinginan untuk keluar di PT PQRS. Namun pengaruh ini didukung secara parsial dimana dalam hubungan antara persepsi politik organisasi dan kepuasan kerja terhadap keinginan untuk keluar gagal dimoderasi dan hubungan antara komitmen afektif dan stres kerja terhadap keinginan untuk keluar berhasil dimoderasi oleh persepsi dukungan organisasi.

Persepsi dukungan organisasi berhasil memoderasi hubungan antara komitmen afektif dan keinginan untuk keluar dengan melemahkan hubungan. Artinya bahwa keinginan karyawan akan cenderung untuk keluar dari PT PQRS saat tingkat komitmen afektif yang rendah namun disertai dengan persepsi dukungan organisasi yang dirasakan ketika seseorang mendapatkan banyak tawaran dari luar untuk pindah terlebih dengan kondisi PT PQRS yang kurang menguntungkan maka seseorang dengan tingkat komitmen afektif yang rendah akan lebih banyak mempertimbangkan untuk keluar, namun ketika hal tersebut terjadi dan terlihat bahwa PT PQRS dirasakan sungguhsungguh dalam memberikan dukungan dan perhatian terhadap karyawan maka akan komitmen afektif akan dapat ditingkatkan 
sehingga tingkat keinginan untuk keluar cenderung menurun.

Persepsi dukungan organisasi juga berhasil memoderasi hubungan antara stres kerja dan keinginan untuk keluar dengan memperlemah hubungan. Artinya bahwa keinginan untuk keluar akan cenderung turun ketika tingkat stres kerja yang tinggi namun disertai dengan persepsi dukungan organisasi yang dirasakan ketika seseorang merasa stres yang tinggi karena memikirnya masa depannya di PT PQRS dengan kondisi perusahaan saat ini yang sedang mengalami penurunan kinerja dirasakanya dukungan organisasi memberikan sedikit efek penurun stres sehingga tingkat keinginan untuk keluar menurun yang ada di PT PQRS. Pada satu sisi dalam pengujian perpsepsi dukungan organisasi terhadap keinginan untuk keluar di PT PQRS memberikan efek negatif terhadap keinginan untuk keluar sehingga dari hasil ini walaupun dirasakanya dukungan yang rendah namun terlihat bahwa karyawan telah menyadari bahwa dukungan yang rendah merupakan hasil dari kondisi perusahaan yang kurang baik.

\section{KESIMPULAN DAN SARAN}

Berdasarkan beberapa temuan yang sudah dijelaskan diatas maka dapat disimpulkan bahwa persepsi politik organisasi dan stres kerja memiliki pengaruh positif signifikan terhadap keinginan untuk keluar di PT PQRS. Sehingga hasil ini memberikan penjelasan mengenai hubungan antara persepsi politik dan stres kerja terhadap keinginan untuk keluar di PT PQRS bahwa semakin besar tingkat persepsi politik orgsnisasi dan stres kerja di PT PQRS maka akan menyebabkan semakin meningkatnya tingkat keinginan untuk keluar karyawan di PT PQRS. kemudian komitmen afektif dan kepuasan kerja memiliki pengaruh negatif signifikan terhadap keinginan untuk keluar di
PT PQRS. Sehingga hasil ini memberikan penjelasan mengenai hubungan antara komitmen afektif dan stres kerja terhadap keinginan untuk keluar di PT PQRS bahwa semakin rendah tingkat komitmen afektif dan kepuasan kerja di PT PQRS maka akan menyebabkan semakin meningkatnya tingkat keinginan untuk keluar karyawan di PT PQRS.Pada pengujian moderasi memberikan beberapa penjelasan yang menarik bahwa persepsi dukungan organisasi berhasil menjadi pemoderasi hubungan antara persepsi politik organisasi, komitmen afektif, kepuasan kerja dan stres kerja terhadap keinginan untuk keluar di PT PQRS. Namun pengaruh ini didukung secara parsial dimana dalam hubungan antara persepsi politik organisasi dan kepuasan kerja terhadap keinginan untuk keluar gagal dimoderasi dan hubungan antara komitmen afektif dan stres kerja terhadap keinginan untuk keluar berhasil dimoderasi oleh persepsi dukungan organisasi.

Dalam analisis kualitatif memberikan dukungan terhadap hasil analisis kuantitatif bahwa keinginan untuk keluar yang ada di PT PQRS banyak di pengaruhi oleh komitmen afektif, kepuasan kerja dan perpsepsi dukungan yang cukup rendah dirasakan serta stres kerja yang tinggi dan dirasakanya politik organisasi

\section{Saran}

Implikasi manajerial ditekan pada kombinasi dari hasil-hasil tersebut guna secara objektif menjabarkan rekomendasi manajerial yang relevan. Pertama, keinginan untuk keluar banyak dipengaruhi oleh stres kerja karyawan oleh karena itu untuk menurunkan tingkat keinginan untuk keluar di PT PQRS maka diperlukanya penurunan tingkat stres yang terjadi di PT PQRS dan meningkatkan tingkat kesejahteraan karyawan.Kedua, keinginan untuk keluar di PT PQRS banyak dipengaruhi oleh tingkat 
komitmen afektif dan kepusan kerja yang rendah. Sehigga meningkatkan komitmen afektif karyawan dengan memberikan lebih banyak perhatian terhadap karyawankaryawan khususnya karyawan muda yang berpotensi untuk dapat membantu kinerja perusahaan dimasa mendatang. Kemudian strategi peningkatan tingkat kesejahteraan karyawan perlu untuk dikaji ulang guna mendapatkan formula yang lebih tepat agar dapat dirasakan mengakomodir ketidakpuasan yang terjadi sehingga kepuasan kerja dapat terjaga atau meningkat untuk program penurunan tingkat keinginan untuk keluar di PT PQRS. Ketiga, keinginan untuk keluar di PT PQRS banyak dipengaruhi oleh faktor politik organisasi yang tumbuh di lingkungan PT PQRS. Sehingga dengan hasil ini untuk menurunkan tingkat keinginan untuk keluar maka persepsi politik organisasi yang tumbuh di PT PQRS perlu untuk di minimalisir dengan mengantisipasi contohcontoh diatas untuk lebih dapat di pertimbangkan guna pengendalian tingkat keinginan untuk keluar di PT PQRS.

\section{REFERENSI}

Ahania, E., Mirzaei, A., \& Fard, A. S. (2016). The Study Of Correlation Between Job Stress And Turnover Intentions Among The Operating Room Nurses In Selected Hospitals Of Tehran University Of Medical Science. Acta Medica Mediterranea, 32(4), 1045-1050.

Arshadi, N., \& Damiri, H. (2013). The Relationship of Job Stress with Turnover Intention and Job Performance : Moderating Role of OBSE. Procedia - Social and Behavioral Sciences, 84(2003), 706-710. https://doi.org/10.1016/j.sbspro.2013.06.631

Bukhari, I., \& Kamal, A. (2015). Relationship between Perceived Organizational Politics and Its Negative Outcomes: Moderating Role of Perceived Organizational Support. Pakistan Journal of Psychological Reseach, 30(2), 271-288.

Cropanzano, R., Howes, J. C., Grandey, A. A., Toth, P., Journal, S., \& Mar, N. (1997). The relationship of organizational politics and support to work behaviors, attitudes and stress. Jounal of Organizational Behavior, 18(2), 159-180.

Dywili, M. (2015). The Relationship between Occupational Stress and Intentions to Quit among Employees at Nkonkobe Municipality, South Africa. Business and Economics Journal, 6(2). https://doi.org/10.4172/2151-6219.1000146

Eisenberger, R., Huntington, R., Hutchison, S., \& Debora Sowa. (1986). Perceived Organizational Support. Journal of Applied Psychology, 71(3), 500-507.

Eisenberger, R., Stinglhamber, F., Vandenberghe, C., Sucharski, I. L., \& Rhoades, L. (2002). Perceived Supervisor Support: Contributions to Perceived Organizational Support and Employee Retention Perceived Supervisor Support: Contributions to Perceived Organizational Support and Employee Retention. Journal of Applied Psychology, 87(July), 565-573. https://doi.org/10.1037//0021-9010.87.3.565

Eric Delle. (2013). The Influence of Perception of Organizational Politcs on Employee Job 
Involvement and Turnover Intentions: Empirical Evidence from Ghanaian Organizations. European Journal of Bussiness and Managment, 5(9), 151-161.

Farooqi Laiba Parvaiz, Saba Batool, Ambar Khalid, Y. A. (2015). Impact of Stressors ( Role conflict, Role overload, Leadership Support and Organizational Politics ) on Job Stress and its subsequent impact on Turnover Intention. International Journal of Business and Management Invention, 4(10), 52-63.

Ferris, G. R., Fedor, D. B., Chachere, J. G., \& Pondy, L. R. (1989). Myths and Politics in Organizational Contexts. Group \& Organization Studies, 14(1), 83-103.

George, J. M., Reed, T. F., Ballard, K. A., Colin, J. \& Fielding, J. (1993). Contact with AIDS patients as a source of work- related related distress: Eff ects of organizational and social support. Academy of Management Journal, 36, 157-171.

Ibrar, M. (2015). The Influences of Employee Job Satisfaction an Organizational Commitment on Turnover Intention. Arabian Journal of Business and Management Review, 6(1), 1-4. https://doi.org/10.4172/2223-5833.1000169

Jamil Amber, Asif Rana Fawad, U. R. (2012). The Role of Perceived Organizational Support as a Moderator in The Perceived Organizational Politics -Job Outcomes Relationship. International Conference on Management, 1231(June), 1231-1245.

Kacmar, K. M., \& Carlson, D. S. (1997). Further Validation of the Perceptions of Politics Scale (Pops): A Multiple Sample Investigation. Journal of Management, 23(5), 627-658. https://doi.org/10.1177/014920639702300502

Kafashpoor, A., Shakori, N., \& Kavoosi, S. (2014). The Impact of Job Stress on Turnover Intention Mediating role of Job Satisfaction and Affective Commitment; Case Study: Mashhad ' s Public Hospitals. Applied Mathematics in Engineering, Management and Technology, 2(1), 96-102.

Kalidass, A., \& Arsiah Bahron. (2016). The Relationship between Perceived Supervisor Support , Perceived Organizational Support, Organizational ... The Relationship between Perceived Supervisor Support , Perceived Organizational Support , Organizational Commitment and Employee. International Journal of Business Administration, 6(5). https://doi.org/10.5430/ijba.v6n5p82

Karatepe, O. M. (2013). Perceptions of organizational politics and hotel employee outcomes. Emerald Insight, 25(1), 82-104. https://doi.org/10.1108/09596111311290237

Kaya, N., Aydin, S., \& Ayhan, O. (2016). The Effects of Organizational Politics on Perceived Organizational Justice and Intention to Leave. American Journal of Industrial and Business Management, (March), 249-258.

Kuo, H., \& Lin, K. (2013). The mediating effects of job satisfaction on turnover intention for long-term care nurses in Taiwan. Journal of Nursing Management. https://doi.org/10.1111/jonm.12044 
Larkin, I. M., Brantley-dias, L., \& Lokey-vega, A. (2016). Job Satisfaction , Organizational Commitment, and Turnover Intention of Online Teachers in the K-12 Setting. Online Learning, 20(3), 26-51.

Leather, P., Lawrence, C., Beale, D. and Cox, T. (1998). Exposure to occupational violence and buffering buffering effect of intra-organizational support. Work and Stress, 12, 161-178.

Lee, Y., \& Mahfar, M. (2013). Jurnal Teknologi Full paper Relationship between Occupational Stress and Turnover Intention among Employees in a Furniture Manufacturing Company in Selangor. Jurnal Teknologi, 1(2004), 33-39.

Mahdi, A. F., Zin, M. Z. M., Nor, M. R. M., Sakat, A. A., Sulaiman, A., \& Naim, A. (2012). The Relationship Between Job Satisfaction and Turnover Intention. American Journal of Applied Sciences, 9(9), 1518-1526.

Mas'ud, F. (2004). Survai Diagnosis Organisasional: Konsep dan Aplikasi. Semarang: Program Magister Manajemen, Universitas Diponegoro Semarang.

Meyer, J.P., Allen, N. . (1997). Organisational commitment. International Review of Industrial Psychology, 12, 175-227.

Meyer, J.P., Allen, N. J. (1990). The measurement and antecedents of affective, continuance and normative commitment to the organization. Journal of Occupational Psychology, 63, 1-18.

Miller, B. K., Rutherford, M. A., \& Kolodinsky, R. W. (2008). Perceptions of organizational politics: A meta-analysis of outcomes. Journal of Business and Psychology, 22(3), 209-222. https://doi.org/10.1007/s10869-008-9061-5

Mosadeghrad, A. M. (2013). Occupational Stress and Turnover Intention: Implications for Nursing Management. International Journal of Health Policy and Management, 1(2), 169176. https://doi.org/10.15171/ijhpm.2013.30

Mxenge S V, Dywili M, B. S. (2014). Organisational Stress and Employees Intention to Quit Amongst Administrative Personnel at The University of Fort Hare, Eastern Cape, South Africa. International Journal of Research In Social Sciences, 4(5).

Novita Sidharta. (2011). Dampak Komitmen Organisasi Dan Kepuasan Kerja Terhadap Turnover Intention. Jurnal Manajemen, 10(2), 129-142.

Olawale, R. A. (2016). Job Satisfaction, Turnover Intentions and Organizational. Journal of Management Research, 8(2).

Olusegun, S. O. (2013). Influence of Job Satisfaction on Turnover Intentions of Library Personnel in Selected Univerisities in South West Nigeria. Library Philosophy and Practice (E-Journal), Paper 914.

Ongori, H. (2007). A review of the literature on employee turnover. African Journal of Business Management, (June), 49-54.

Palupiningdyah, N. syarifah. (2014). Peran Stres Kerja dan Kepuasan Kerja untuk Mengurangi 
Turnover Intention. Jurnal Dinamika Manajemen, 5(2), 220-227.

Pathak, D. (2012). Role of perceived organizational support on stress-satisfaction relationship : An empirical study. Asian Journal of Management Research, 3(1), 153-177.

Perryer, C., Jordan, C., Firns, I., \& Travaglione, A. (2010). Predicting Turnover Intentions: The interactive effects of Organizational Commitment and Preceived Organizational Support. Emerald Insight, 33(9), 911-923.

Priya, N Kamakshi, D. M. K. S. (2016). A Study On Relationships Among Job Satisfaction, Organizational Commitment And Turnover Intention In Kolors Healthcare India Pvt Ltd , Chennai. International Journal of Advanced Research in Management, 7(1), 58-71.

Randall, Marjorie L, Cropanzano, Russell, Bormann, Carol a, Birjulin, A. (1999). Organizational politics and organizational support as predictors of work attitudes, job performance, and organizational citizenship behavior. Journal of Organizational Behavior, 20(2), 159-174. https://doi.org/10.1002/(SICI)1099-1379(199903)20:2<159::AID-JOB881>3.0.C0;2-7

Rhoades, L., \& Eisenberger, R. (2002). Perceived Organizational Support: A Review of the Literature. Journal of Applied Psychology, 87(4), 698-714. https://doi.org/10.1037//0021-9010.87.4.698

Salleh, R., Nair, M. S., \& Harun, H. (2012). Job Satisfaction , Organizational Commitment , and Turnover Intention: A Case Study on Employees of a Retail Company in Malaysia. International Journal of Social, Behavioral, Educational, Economic, Business and Industrial Engineering, 6(12), 3429-3436.

Sekaran, U. (2006). Metodologi Penelitian untuk Bisnis (Edisi 4). Jakarta: Salemba Empat.

Sekaran, U., \& R, B. (2010). Research Methods for Business: A Skill- Building Approach. London: John Wiley and sons, inc.

Shahrul Nizam, Mohd Nur Ruzainy. Siti Sarah, Yuyaneswary Santhasaran, V. B. (2016). The Relationship between Occupational Stress, Employee Engagement and Turnover Intention. International Conferece on Business and Economics, 10, 21-23.

Simranjeet Kaur Sandhar, S. V. (2014). A Relationship Between Job Satisfaction and Turnover Intention in Information Technology Sector. Pezzottaite Jounals, 4(3), 1521-1531.

Sugiyono. (2004). Metode Penelitian Bisnis. Bandung: Alfabeta, CV.

Tnay, E., Ekhsan, A., Othman, A., Siong, H. C., Lim, S., \& Lim, O. (2013). The influences of job satisfaction and organizational commitment on turnover intention. Procedia - Social and Behavioral Sciences, 97, 201-208. https://doi.org/10.1016/j.sbspro.2013.10.223 